\title{
Genetic pesticides
}

\section{Monsanto goes ahead with trials}

\section{Washington}

THE Monsanto Company will shortly notify the Environmental Protection Agency of plans for the first field test of a genetically-engineered microbial pesticide. In doing so, Monsanto will become the first company to break with the convention whereby private companies have voluntarily sought approval for genetic engineering experiments from the Recombinant DNA Advisory Committee (RAC) of the National Institutes of Health (NIH).

The proposed test consists of planting corn seeds coated with a modified strain of Pseudomonas fluorescans expressing the gene for Bacillus thuringiensis toxin. This toxin has been used for many years as an insecticide, and protects growing corn plants from attack by black cut worm. $P$. fluorescans is found naturally in association with corn roots, and it is hoped that the modified bacterium could be a continuous in situ source of insecticide.

The company's decision to sidestep RAC was doubtless influenced by a preliminary injunction granted last spring by US District Court Judge John Sirica which prevents NIH from approving field trials of recombinant organisms without first preparing a formal environmental assessment on a field trial "program". The case is now before the US Court of Appeals. However, the injunction applies only to institutions that receive federal funds for research. Since Sirica's injunction was granted, the Environmental Protection Agency (EPA) has moved to assert its jurisdiction in this area. The agency published an interim policy for field trials of modified organisms in October (see Nature 25 October, p.695).

Under the new EPA policy, 90 days' notice must be given for field tests of " genetically altered or manipulated" organisms. The test will be allowed to proceed if EPA raises no objection. Although EPA will not formally call on RAC to examine the experimental protocol, there is "total agreement"' between EPA and RAC on the sort of data that are needed to support a notification, according to Dr Amy Rispin of EPA. EPA has representatives on some RAC subcommittees, thus ensuring "commonality of approach". Its actions in moving to regulate environmental releases of altered organisms have generally received high marks in the industry. EPA will require information on how the modified organism has been constructed, on the ecology of the host organism and on how release will be performed. Outside consultants will be employed to review areas where EPA has insufficient in-house expertise.

Monsanto has conducted preliminary greenhouse and growth-chamber experiments with $P$. fluorescans which indicate that it survives in corn plant roots for only 8-10 weeks if applied to the seed at planting. The modified strain does not even survive that long, according to Dr Robert Kaufman of Monsanto. Levels of expres-

\section{Agencies vie for control}

\section{Washington}

ThE Environmental Protection Agency (EPA)'s competence to regulate environmental releases of genetically engineered microorganisms came under harsh scrutiny last week in Congress. At a hearing on biotechnology chaired by Representative John Dingell, EPA's assistant administrator for research and development, Bernard Goldstein, was grilled on an internal EPA memorandum asserting that the agency had "insufficient resources and no designated management plan for developing a cross-cutting biotechnology assessment programme in 1985",

The memorandum, by John Fowle, biotechnology coordinator in EPA's office of research and development, indicates that the office has 6.9 full-time equivalent staff and $\$ 1.3$ million dollars committed to biotechnology assessment in 1985. It concludes that 20 full-time staff and $\$ 4$ million would be required for a "credible" biotechnology programme, which would have 20-30 per cent of resources devoted to fundamental research.

Representative Gerry Sikorsky said that biotechnology assessment was low on
EPA's list of priorities and lamented that he "heard a lot of good talk" about regulation of biotechnology but that "there's little going on so far". Dr Goldstein said the biotechnology budget for fiscal year 1985 within the agency was more than $\$ 1.6$ million, but that the total budget for process regulation exceeded $\mathbf{\$ 5 0}$ million.

EPA is not the only agency where attention is being given to regulation of biotechnology. Orville Wright, assistant secretary for science and development at the US Department of Agriculture, endorsed a proposed National Biological Impact Assessment Program to be located within the department. The programme would be research-based and would carry out "stepwise" assessments of proposed environmental releases of modified organisms. It is unclear how such a programme would be used by other regulatory agencies. Dr Bernadine Bulkley of the White House science office said the office would shortly propose a new interagency scientific review mechanism to ensure the best scientific advice is brought to regulators and to minimize overlapping jurisdictions.
Tim Beardsley sion of $B$. thuringiensis toxin are comparable with those in the source bacterium, and other metabolites also appear to be expressed at normal levels. $B$. thuringiensis toxin is specific to lepidopterous insects in its effects.

The test will be conducted at a research farm near Monsanto's headquarters at St Louis, Missouri, on a plot measuring less than one acre. The persistence of the modified bacterium will be monitored by tests specific to the toxin gene and the protein product. Kaufman points out that the bacterium is easily destroyed by household bleach, and that fumigation with methyl bromide could also be used to prevent the spread of the organism should it not behave in the test as expected. If the bacterium does decline after a few weeks, like the natural variety, it may be left in the soil over winter to see whether it will reappear spontaneously the following year. Kaufman will not be drawn on whether the new organism is likely to be economically competitive as a pesticide, saying the modified organism to be treated is still a "prototype"'.

Tim Beardsley

\section{US food agency

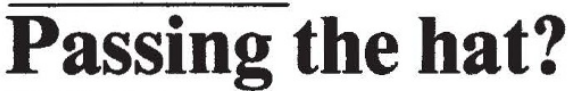

\section{Washington}

THE new Commissioner of the Food and Drug Administration (FDA), Frank Young, seems to have taken to heart the spirit of the season - budget-cutting, that is - by circulating within the agency a proposal to defray some of FDA's research costs with private contributions.

The idea is apparently not a new one; each time it has come up before, worries over the obvious conflict of interest problem have resulted in a quick burial of the proposal. But given the enthusiasm of President Reagan and his appointees for "user fees" and for government-industry cooperation, the idea may survive at least a bit longer this time around. It has in fact received a strong endorsement from the scientific advisory board of the National Center for Toxicological Research, the FDA laboratory in Arkansas that carries out studies of the health effects of food additives, drugs and other substances.

As foreseen by Young, corporations and private foundations would contribute to a "blind trust" that would support the agency's research. Contributors would not be able to earmark their money for any specific projects. Presumably, the contributors from the food and drug industries would benefit in particular from research carried out by FDA on test methodologies. (In general, the manufacturers are required to perform their own safety testing on products they submit to FDA for licensing).

An FDA spokesman emphasized that Young had in no way committed himself to the idea and that, in any event, its implementation would require legislative approval.

Stephen Budiansky 